\title{
Geoffrey Bolton Lecture- From bolshevism to populism: Australia in a century of global transformation ${ }^{1}$
}

\author{
Stuart Macintyre
}

University of Melbourne

One hundred years ago last week, an obscure Russian named Vladimir Ilyich Ulyanov directed a seizure of power in the Russian capital of St Petersburg. Ulyanov was a professional revolutionary, better known as Lenin (because he had been exiled in Siberia, close to the Lena river), and was living in Switzerland in April 1917 when Germany took him back to his homeland to foment discord there.

For Germany was at war with Russia and the growing strain of that conflict had brought down the tottering Tsarist regime in the previous month. Since Lenin was known to oppose the war, his arrival in Russia was calculated to weaken the efforts of the new Provisional Government to revive that country's military effort. And so it did. With his call for an end to the war, Lenin's Bolshevik Party (Bolshevik meaning the majority wing of the Russian Social-Democratic Workers Party) grew rapidly from some 10,000 members in March 1917 to 400,000 by November.

Effective power passed during 1917 from the Provisional Government to local councils of workers, soldiers and peasants, known as soviets, which took over the running of factories, removed unpopular military officers and redistributed the landholdings of the nobility. With their

\footnotetext{
1 This is the text of the Geoffrey Bolton Lecture for 2017, which was delivered in Perth at the invitation of the State Records Office of Western Australia. I was asked to mark the centenary of the Russian Revolution and offer observations on the rise of populism 100 years later. In doing so, I drew extensively on my biography of Paddy Troy, cited below, and a more recent biographical essay, 'Geoffrey Bolton: A Lifetime of History', A Historian for All Seasons: Essays for Geoffrey Bolton ed. in Stuart Macintyre, Lenore Layman and Jenny Gregory, (Melbourne: Monash University Publishing, 2017), 1-39. In preparing the lecture for publication, I have restricted footnotes to the sources of quotations and specific references.
} 
slogan of 'Bread, Peace and Land' and call for 'All Power to the Soviets', the Bolsheviks seized control of the bridges and railway stations in St Petersburg in early November (October in the old Julian calendar) and then bombarded the headquarters of the Provisional Government in the Winter Palace into submission. Through a national congress of soviets they proceeded to issue a series of decrees that included the declaration of peace, the transfer of land to the peasants, workers' control of industry, self-determination for the national minorities in the far-flung Tsarist empire, new marriage laws, adoption of the Gregorian calendar, reform of the alphabet and much else. By July 1918, when Bolsheviks renamed their party the Communist Party, they were able to proclaim:

abolition of exploitation of man by man, the complete elimination of the division of societies into classes, the ruthless suppression of the exploiters, the establishment of a socialist organisation of society, and the victory of socialism in all countries. ${ }^{2}$

Even before the Bolsheviks seized power, those who had most to lose resisted their loss of wealth and authority. By 1918 army generals, reinforced by Russia's allies (the British forces included a little over 100 Australian soldiers), were fighting to regain control. A counter-revolutionary war was waged over the next three years with extraordinary brutality. It cost the lives of more than 3 million combatants and civilians, with another 2 million dying of typhus, smallpox, dysentery and other diseases, plus another 6 million from starvation. ${ }^{3}$ In December 1917, the Bolsheviks created an Emergency Committee for Combating Counter-Revolution and Sabotage, known from its Russian initials as Cheka. In the following year, as anti-Bolshevik forces closed in on the stronghold where the royal family was held, the Cheka killed the Tsar, the Tsarina and their children. The Romanovs were among 300,000 victims of the Cheka during the civil war.

Lenin was a man of unbending determination and self-discipline, personally modest but utterly convinced of his own judgement and intolerant of dissent. He conceived his revolutionary party as a vanguard force leading the proletariat to its historic mission of overthrowing capitalism, that term vanguard only one of the military metaphors he employed. The party's

2 SA Smith, The Russian Revolution: A Very Short Introduction (Oxford: Oxford University Press, 2002), 40: doi.org/10.1093/actrade/9780192853950.003.0003.

3 Smith, The Russian Revolution, 47. 
iron discipline was shaped by Russian circumstances that gave very little space for open political activity, a fateful characteristic that strengthened during the civil war. All opposition was stamped out.

Then, with Stalin's capture of the Communist Party after Lenin's death, there were the purges and the unleashing of a Terror that carried off anyone suspected of disloyalty. The forced collectivisation of agriculture and suppression of national minorities killed millions. Stalin replaced one-party rule with personal dictatorship and his cult of the all-powerful, all-knowing leader prefigured the way that communist regimes installed after the Second World War produced their own dictators. Kim Jongun, the son and grandson of such dictators, personifies the appalling consequences.

The 100th anniversary of the Russian Revolution finds few celebrants. Communism was discredited by the revelations in 1956 by Stalin's successor Khrushchev of the crimes committed in its name. It fell abruptly in Eastern Europe at the end of the 1980s and then in Russia with almost no resistance, living on in China and a few other countries in name only. By the time of the Cold War it was common to see the Russian Revolution as a tragic wrong turn of history, and that remains the dominant reading. Why, then, did such a ruinous cause command the loyalty of so many people? Totalitarian rule can perhaps explain the 40 per cent of the world population who lived under communist regimes as late as 1985, but what of those who voluntarily joined and sustained communist parties elsewhere? Communism was a unique political force with an organisational structure that encompassed every country in the world, and it attracted millions of adherents in France, Italy and India.

The events in Russia at the end of 1917 set off a wave of revolutionary sentiment that swept across the globe. In its aftermath tobacco workers in Cuba formed their own soviets, while young radicals in Asia hailed the dawn of a new era. Here in Western Australia, John Curtin welcomed the Russian Revolution as vindication of his opposition to conscription. In editorials in the Westralian Worker he rejoiced in the downfall of tyranny, joined with the Bolsheviks in calling for the end of a senseless imperial conflict. 'One nation only has passed victorious through the ordeal', he would write, 'and has now risen renovated and rejuvenated, a star of promise for the world, a beaconlight for our future guidance'. ${ }^{4}$

4 John Curtin, 'Destruction and Construction: The Old Order and the New', Westralian Worker, 5 March 1920. 
The fall of the Romanovs was followed by that of the Hapsburgs, the ruling family of Austro-Hungary, and then by the Ottoman Emperor in Turkey and the Kaiser in Germany. By the end of 1918 all prewar regimes from Vladivostok to the Rhine had gone, though Lenin's expectation that the Russian Revolution would bring world revolution was mistaken. Wherever communists attempted to seize power outside Russia they were put down in a cycle of revolution and counter-revolution. ${ }^{5}$ The savagery of this contest is difficult to exaggerate. As nation-states replaced empires, there was a chain reaction of civil wars that extended as far west as Ireland. The principle of national self-determination that President Wilson espoused at the Paris Peace Conference failed to accommodate ethnic and religious minorities within the new states, many of which were baptised in the blood of genocide. The new regimes were characterised by a vengeful, militarist and authoritarian nationalism that Mussolini turned into fascism, Hitler into Nazism and from which other dictators formed their own variants. The League of Nations proved impotent in the face of their aggression.

Apart from the waste and destruction of the unfinished war, the victors who determined the Treaty of Versailles failed to rebuild the international economy. The financial demands of the conflict left huge debts, and the peace settlement severed trading links. Inflation wiped out savings, and a financial imbalance plunged the world economy into a deep Depression at the end of the 1920s. In such circumstances communism attracted support, here as elsewhere.

Among those drawn to this demanding creed was a young Western Australian, Paddy Troy. Born in Port Melbourne in 1908, he had come to Fremantle during the war when his father brought a vessel across the Bight to assist in dredging a naval base. After leaving school Paddy worked in a series of casual temporary jobs-a greengrocer's delivery boy, a storeman's assistant, a shearers' rouseabout. He changed his occupation frequently, partly because that's what teenagers do, partly because he stood up for his rights and partly because of the seasonal and uncertain nature of the economy.

5 A recent general account is Robert Gerwarth, The Vanquished: Why the First World War Failed To End (New York: Farrar, Straus \& Giroux, 2016). 
His father earned good wages but had no security of employment; and since Paddy was the eldest boy of 10 children, he was expected to contribute to the household. He went to sea on a merchant vessel and later worked under his father's command dredging the port of Geraldton. A few days before Christmas 1929 that work was suspended and the crew was laid off. For the next three years the dredging was intermittent. The Troy family fell back on relief work; this was restricted to married men but, with his father's health failing, Paddy was given permission to earn the meagre allowance. He joined the Australian Workers Union, which covered relief workers, and became closely involved in the local labour movement. His talent as an organiser was quickly spotted and he was appointed campaign manager for the Geraldton district council of the Australian Labor Party (ALP). A parliamentary career beckoned.

But in 1934 he submitted his resignation to the ALP. 'My reason for resigning', he wrote, 'is because I have decided to link up with the Communist Party'. ${ }^{6}$ What brought a young man in an isolated regional town in an isolated state of a remote country to this decision? He had met up with some communists sent from Perth on relief work, one of them from a Jewish Russian family. He had read some communist literature, and was particularly attracted to the Soviet magazine, USSR in Construction, which extolled the achievements of the workers' state. Most of all, he was trying to understand the inability of the State Labor Government led by Philip Collier to withstand the misery and distress of mass unemployment. A purposeful, collective endeavour to build a new social order free of exploitation exerted an irresistible appeal.

'I am convinced that I am on the right track at last', he declared in his letter of resignation, and 'knowing that my path will be rough, I am fully prepared to accept whatever may be my lot'. That path was rough. When Paddy joined the Communist Party of Australia, there were no more than 100 Western Australian comrades who kept up a round of demanding but largely unrequited activity. Having married in 1935, he took work where he could find it: initially as a rigger on a small goldmine at Youanmi until he was blacklisted for leading a strike, and then on building sites around Perth.

6 Quoted in Stuart Macintyre, Militant: The Life and Times of Paddy Troy (Sydney: George Allen \& Unwin, 1986), 38. 
The outbreak of the Second World War intensified the rigours of his activism, for the Communist Party opposed the war until 1941 as another imperialist conflict. He was one of the victims of an unusually effective officer in the special branch of the Western Australian police force, Ron Richards, who planted both informants and evidence to obtain convictions for breaches of the wartime National Security Act. Paddy was an early victim, arrested in May 1940 for possession of a communist publication and sentenced to three months hard labour in the Fremantle prison.

Soon after release he found work on the waterfront. From his time on the dredges he was a member of the Coastal, Dock, Rivers and Harbour Works' Union (CDRHWU), which provided labour for a number of jobs: harbour maintenance, ship repair, tug hands, watchmen and the men who loaded and unloaded ships when demand exceeded the membership of the Lumpers' Union (as the Western Australian branch of the Waterside Workers Federation was then known). The members of the CDRHWU made up a residual workforce performing tasks not covered by the more powerful lumpers, seamen and craft unions. Most worked on a casual basis, engaged for a specific job and then laid off. If you were on your uppers and there was no other prospect, you would go down to the waterfront and sit outside the Fremantle Trades Hall on Marine Parade awaiting a call. To find employment you might have to give a kickback to the foreman, and the nearby Esplanade Hotel was commonly used for the transaction. A transient, dispirited membership made for a tame union, but the wartime shortage of labour allowed for improvement and Paddy was elected an organiser in 1944. He had the landlord of the Esplanade Hotel install benches on the veranda to rescue workless men from the indignity of sitting in the gutter. By 1948 he was the union secretary, re-elected annually for the next 25 years.

His was a form of union leadership that has disappeared. He did not wear one of those off-putting uniforms emblazoned with insignia. His pay was that of the members. Every morning he would attend the pick-up and then visit the worksites to ensure safe working conditions. While insisting that arbitration gave nothing to the workers they did not fight for, he appeared repeatedly before the State Arbitration Court to improve awards and pursue disputes. He secured attendance money for those who were not engaged, a roster system to end favouritism, penalty rates for those doing the dirtiest work, annual leave and eventually tenure of employment with a regular wage. He was the best-known union activist in the West, notorious for his militancy, respected for integrity and effectiveness. 
As a communist, he lent his union's support to other unions and to those fighting for their rights: hence it gave assistance to the Aboriginal pastoral workers in the Pilbara and banned Dutch ships that were carrying supplies to put down the independence movement in Indonesia. On Saturday mornings you would find him selling the communist paper in High Street, on Sundays he was speaking on the Perth Esplanade. He served as president of the state branch of the Communist Party when it was a force and marched under the union banner on May Day as the numbers fell away. He stood for federal and state parliament as a communist candidate on 11 occasions, lucky if he saved the deposit.

His was a form of class politics based on his experience and membership of an occupational community. Pat and Mabel lived from the 1940s in a substandard rented house in East Street, Fremantle, with their five children and often relatives as well. After the owner evicted them to use the site for a service station, they moved in 1954 to a Housing Commission home in Palmyra. It was a clean, new, timber-framed asbestos box with three bedrooms and another on the front veranda occupied by one of the boys and a homeless retired waterside worker, but it gave them an indoor bathroom for the first time. Both Pat and Mabel had limited schooling; on birthdays the children were given books. They listened to the $\mathrm{ABC}$ news and parliamentary broadcasts; all the family was expected to contribute to discussion of current affairs at the dinner table. Two of the boys completed university degrees and one went to sea. The sisters trained as secretaries; one became an accountant, another became a federal electoral officer.

Here already we see the forces that were extending the horizons of workingclass families: full employment, public housing, better health care, greater educational opportunity, a narrowing of the gap between rich and poor. The historian Eric Hobsbawm has suggested that governments of the advanced capitalist countries embarked on these improvements after the Second World War to meet the challenge of communism, which was at its height during the Cold War. ${ }^{7}$ I would see them more as a determination to solve the deep problems left by the First World War, problems that had led so quickly to a second. Whatever the explanation, the poverty and insecurity that had persuaded men and women such as Paddy Troy to throw in their lot with communism were in retreat, and so too was their cause.

7 Eric Hobsbawm, Age of Extremes: The Short Twentieth Century 1914-1991 (London: Michael Joseph, 1994), Chapter 9. 
He retired from the union in 1973, the very year in which a quartercentury of sustained growth and social improvement came to an end with the OPEC (Organization of the Petroleum Exporting Countries) oil crisis. From then until the end of the 1980s Australia and other Western countries searched for a solution to unemployment, inflation, the collapse of industries that had once offered job security, financial volatility and fiscal difficulties that choked public provision. These problems might have been expected to revive working-class activism, even breathe life into communism. They didn't, for reasons to which I shall return, but first I want to say a little about the history I have related.

I became interested in the life of Paddy Troy when I was teaching at the new Murdoch University in 1979. He had died the previous year but I befriended his eldest son, Patrick, who showed me a collection of his father's books and papers. After moving to Melbourne in 1980, I returned here regularly to undertake biographical research. The records of the Labor Party were in the Battye Library, but it held few communist ones at that time (it has since acquired the extensive collection of Annette and Duncan Cameron). ${ }^{8}$ The records of Paddy's union were in its office in Fremantle, eloquent testimony to his concern to document its work. The minute books gave extensive accounts of meetings and campaigns, with leaflets and bulletins pasted in.

Since then a remarkable body of additional sources has become available. Newspapers are now digitised and online, so you no longer have to turn over the pages hoping the name you are after will catch your eye-you can use it as a search term and locate every single item. The State Records Office has taken advantage of the new technology to make its enormous volume of records on government agencies accessible. And the same holds for Commonwealth records, including those created by the Australian Security Intelligence Organisation (ASIO) and its predecessors. We now know in detail of the methods that Ron Richards used to obtain convictions during the war and his manipulation of evidence after it. ${ }^{9}$

8 Michal Bosworth, comp., Well Read: A Bibliography of Communist Party \& Other Sources Collected in Western Australia by Annette and Duncan Cameron, donated to the J. S. Battye Library (Sydney: Search Foundation, 1997).

9 See especially the files for Western Australian communists in National Australian Archives (NAA), Series A6119. 
One of the most shocking acts of the Bolsheviks after they seized power at the end of 1917 was to publish the wartime diplomatic correspondence of the Allies, which revealed that their protestations of clean hands were bogus: there in the official record was the division of territorial spoils on which they had secretly agreed. Archives are not just the raw material of history; they are a fundamental principle of accountable government. Granted, there is an interval before the official record is opened to the public; even so, the knowledge that the full documentary evidence will be retained and eventually available serves as a check on the abuse of power.

Now you could hardly call the Soviet Union or the present Russian Federation models of archival openness; for that matter ASIO is reluctant to release all its records to the National Archives, and withholds or redacts portions of the files that can be used. Paddy Troy's ASIO file is a case in point. It is replete with details of his trips to attend union as well as political meetings in the east (the travel agent routinely forwarded all bookings to security), and much else, but it withholds the identity of the informer who reported (very inaccurately) on the comrades who gathered with Paddy at a dinner to welcome the black American singer and communist, Paul Robeson, to Perth in $1960 .^{10}$

Paddy's eldest son, Patrick Troy, experienced ASIO's inefficiency when he landed in England at the end of 1958 to begin an advanced course in engineering run by the Federation of British Industry. He was interrogated at length by two retired naval officers who said they had evidence provided by an Australian government agency of him inciting workers to strike on the Fremantle docks. That a 22-year-old would wield such influence was inherently implausible and Pat was able to persuade them ASIO had confused him with his father. ${ }^{11}$

There is a story told of a book launch in Perth in 1972 at which a large audience assembled to celebrate the author's achievement. It went well apart from one discordant note when the stentorian voice of Paddy Troy was heard asking 'what about my union records?' 12 The story is possibly apocryphal since the minute books were all safely in the union office when I used them eight years later, but the author had interviewed Paddy (and just possibly borrowed his union's minute books) when writing a study of Western Australia during the Depression years.

10 Patrick Lawrence Troy, vols 1-3, NAA A6119, 1235-7.

11 Personal information; see also Patrick Nicol Troy, NAA A6119, 5897.

12 Information from members of the Maritime Union of Australia in 1983. 
This historian was Geoffrey Bolton, his book A Fine Country to Starve In. Geoffrey's appreciation of archives went back to his time as an undergraduate when he embarked on a study of Alexander Forrest. He went on to archival research in England and Ireland, and subsequently in all the principal Australian repositories. His histories were not restricted to the documentary record, for he was an early practitioner of oral history, and a keen reader of newspapers and contemporary publications; he picked up information from myriad sources and stored it in his capacious memory. Geoffrey was the most versatile of a distinguished generation of Australian historians.

A quarter-century younger than Paddy Troy, his life and career illustrate the new possibilities that opened up in the second half of the last century. Born in 1931, he was the child of English immigrants who lived modestly in North Perth. By means of scholarships, he made his way from the local state school to Wesley College and the university. His talent secured a postgraduate award and then another that enabled him to undertake further training at Oxford. From there he proceeded to a research fellowship at The Australian National University, an academic post at Monash, and then chairs at the University of Western Australia, Murdoch, the University of Queensland and Edith Cowan. There were just seven universities teaching 30,000 undergraduates when he became one of them. There were 40 universities with an enrolment of half a million when he retired in 1996, marking the extraordinary growth of the professions.

Geoffrey was never attracted to communism. He tried to read Marx but was repelled by the hectoring style of argument. He wondered why intelligent students a few years ahead of him at university such as Dorothy Hewett could be so committed to such a doctrinaire faith. While editor of the student newspaper, Pelican, he supported Robert Menzies' 1950 legislation to outlaw the Communist Party but drew back during the subsequent constitutional referendum to allow that ban after he witnessed Young Liberals shouting down their opponents on the campus. ${ }^{13}$

He thought he inherited his aversion to the abuse of power from his parents. They came from that frugal and cautious section of the lower middle classes that Menzies invoked in his celebrated wartime broadcast

13 Geoffrey Bolton in Pelican, 5 May 1950, and letter to the editor, West Australian, 26 September 1951. 
to 'The Forgotten People', acutely conscious that whether business or unions held the whip hand it was 'the people in the middle' who were likely to get hurt. ${ }^{14}$ One of the works he read in his first year at university made a lasting impression. The Marquess of Halifax, a politician during the Restoration period, upheld moderation and compromise against extremism and intolerance. The term trimmer was levelled against him to denote opportunism and expediency. In a celebrated essay, The Character of a Trimmer (1684), Halifax insisted that prudent statecraft required holding the centre and pursuing the middle way.

Geoffrey was also drawn to the middle way. He chose it as the title of his volume in The Oxford History of Australia, which runs from the Second World War up to closing years of the last century. It relates the fortunes of a country emerging from its wartime emergency, achieving economic growth and social progress, pragmatic and adaptive, but mistrustful of extremes. In relating the downfall of Gough Whitlam, whose hallmark was 'Crash Through or Crash', Geoffrey remarked that the children of the Depression and the postwar migrants both sought security and modest comfort and were accordingly 'apprehensive of too much change'. ${ }^{15}$ Later generations are inclined to take for granted the transformation that occurred in the domestic lives of ordinary people during these years: hot water in the kitchen, a refrigerator, a washing machine, clean surfaces and fresh paint. But change was thrust upon Australia after 1975. The prolonged difficulties in restoring the country's economic fortunes brought a new edginess and rancour to public life. The far-reaching alterations of national policy that followed in the 1980s swept away many fixtures of the middle way: the arbitration system and income security, the protection of local industries, the public enterprises and agencies that sustained rural communities.

The disappearance of these safeguards is commonly credited with economic reform that allowed the market to allocate resources more efficiently, lift productivity and lay the foundations for a further run of uninterrupted growth that lasted from the mid-1990s to the present. Geoffrey's account of the changes in his Oxford history and reflection upon their effects in his 1992 Boyer lectures was less ebullient.

14 Geoffrey Bolton, interviewed by Neville Meaney, 11 September 1985, National Library of Australia (NLA), TRC 2053/6.

15 Geoffrey Bolton, The Oxford History of Australia, Volume 5, 1942-1988 (Melbourne: Oxford University Press, 1990), 243. 
He linked the deregulation of finance to reckless speculation and extravagance, the pursuit of personal advantage to a weakening of probity. He deplored the excesses of what he called a new Gilded Age, the growth of inequality, the crude adversarialism in public life and the exploitation of resentments and fears.

Both Paddy Troy and Geoffrey Bolton lived busy lives. Widely known and respected, they seldom declined requests to lend their expertise and influence to all sorts of projects and causes. The one was directive, confrontational and impatient. The other was conciliatory, preferring persuasion to argument. They moved in different circles, held different understandings of the world. But each applied his efforts to the common good.

Paddy Troy witnessed the modernisation of the Australian economy, and the way that improvement of wages, working conditions and welfare blunted the edge of working-class militancy. Geoffrey Bolton saw the triumph of globalisation and the new discontents it created. Those discontents have grown to threaten the neoliberal order that was constructed in the 1980s. Celebration of the apparent triumph of market democracy following the collapse of communism has given way to prognostications as anxious and gloomy as those of the 1930s.

Let me try to sketch the chain of events that brought on this disillusionment. First, the economic policies known as the Washington consensussmaller government, fiscal discipline, trade liberalisation and financial deregulation-came to grief in 2007 as the result of excessive leverage of credit. The financial crisis spread rapidly to all market economies, the bank bailouts and forced sales of assets wreaking havoc. Partly because of the European Union's enforcement of austerity, there was mass unemployment in countries such as Greece, Spain and Italy. This in turn exacerbated antagonism to governments, politicians, the established parties and the conventional forms of liberal democracy. Italian voters who had turned to Silvio Berlusconi, the media tycoon and sexual predator, prefigured the election of similar leaders-in Europe, Turkey, the Philippines and now, it seems, the United States — whose principal appeal was that they defy the conventions and safeguards of representative government.

The painfully slow economic recovery has brought no relief. Business enterprises cut costs by offshoring operations and replacing permanent employees with part-time and casual workers. Inequalities of income and 
wealth, which had been rising since the 1980s, have reached levels not seen since the early twentieth century. Except for the rich, a whole generation in the United States has experienced a decline in its standard of living. The International Monetary Fund now recognises that the lack of wage growth, and the precarious, insecure nature of employment, is stifling the consumer demand needed to restore business activity. But without unions able to drive up wages, there is little prospect of such stimulus.

Meanwhile the apparent triumph of the West proved illusory. With the fall of communism, the free market was assumed to be synonymous with political freedom, globalisation a force for integration. But China's economic transformation was accompanied by a tightening of oneparty rule, heavy military expenditure and assertiveness, while Russia's autocratic ruler enforced the excision of part of the Ukraine. The United States entered the present century as the undisputed super-power, but President Bush's war on terror revealed the limits of that supremacy. It also created turmoil in the Middle East, fanning tribal, religious and ethnic conflict that sent waves of refugees fleeing the region in search of sanctuary. Intercommunal violence is not restricted to the Middle East: it began in the Balkans with the fall of communism and we may think of the prolonged civil wars in Sri Lanka and the Horn of Africa, both of which have brought refugees here. But the number coming to Australia is a tiny fraction of those entering Europe, and in countries as different as Poland and Hungary, the Netherlands and France, most recently Austria and the Czech Republic, they have fostered mass support for parties promising to defend the nation against intruders.

It is common to describe the practitioners of such politics as populists and to explain their appeal by reference to the discontents I have summarised so baldly. Populism is a widely used but poorly defined term. Literally it means support for the concerns of the people, but who are the people and who speaks for them? In pre-revolutionary Russia the populists were radical intellectuals, not unlike Lenin, who identified with the mass of the peasantry and helped bring down the Tsar. The populists in the United States at the end of the nineteenth century had a similar radical edge. In its modern form, populism is more usually associated with the right. It pits a homogenous and virtuous people against the educated, cosmopolitan elites who spurn and betray them. I note that the word elites is what is known in semiotics as a floating signifier: it has no agreed-upon meaning but functions as a richly expressive term of abuse. The same is true of the word populism, and I find it of limited utility in understanding the present 
grievances. Populism certainly thrives on the feeling of being left behind, but it hardly offers a solution. Why would struggling Americans vote for a president who combines extraordinary wealth with poor employment practices and repeated recourse to Chapter 11 bankruptcy provisions?

Communism was a response to hunger, deprivation and economic crisis. It began as a movement of the European working class. It was taken up and had its greatest impact among the desperately poor peasants outside Europe living under imperial rule, for whom it served as a doctrine of emancipation and national independence. The descriptor populism, on the other hand, gathers up responses to a range of grievances that take different forms and draw on different bases of support. Some are grounded in austerity, inequality and insecurity, but they extend to hostility against ethnic minorities and identity politics. The political disengagement goes beyond hostility to politicians and finds expression in attacks on secularism, a free press and independent judiciary.

A final, provocative suggestion. Movements exploiting these grievances have had an undeniable effect on democratic polities. They have cut away the support base of established parties, rendering social democracy powerless in Europe and forcing the main conservative ones to accommodate their demands (as in the United States) or share the same fate. But not in Australia. Here we have had periodic insurgencies such as the ill-fated 'Joh for PM' in the 1980s, Pauline Hanson's One Nation Party in the late 1990s and again more recently. All of these revolts have been ephemeral; none has looked like disturbing the established political alignment. And the same holds for Canada and New Zealand.

What do these countries have in common? All have enjoyed economic success and escaped the erosion of living standards experienced elsewhere. All began as settler societies, long troubled by their appropriation of the land of their Indigenous peoples and practising racial exclusion to a greater or lesser degree before they embraced new settlers from a wide variety of cultural backgrounds. All are lands of opportunity, by no means free of prejudice and animosity, but able to accommodate difference. It may well be that Geoffrey Bolton's middle way is not yet spent. 
This text is taken from ANU Historical Journal II: Number 1, published 2019 by ANU Press, The Australian National University, Canberra, Australia.

doi.org/10.22459/ANUHJII.2019.16 